\title{
Dynamic Problem-Solving Processes in a Web-Based Cooperative Learning Environment for an Accounting Course
}

\author{
Kai-Wen Cheng ${ }^{1}$ \\ ${ }^{1}$ Airline and Transport Service Management, National Kaohsiung University of Hospitality and Tourism, \\ Taiwan \\ Correspondence: Kai-Wen Cheng, Airline and Transport Service Management, National Kaohsiung University \\ of Hospitality and Tourism, 81271 No.1, Songhe Rd., Xiaogang Dist., Kaohsiung City, Taiwan (R.O.C.). Email: \\ kevin1188@mail.nkuht.edu.tw
}

Received: May 18, 2018

Accepted: June 22, 2018

Online Published: July 8, 2018

doi:10.20849/jed.v2i2.415

URL: https://doi.org/10.20849/jed.v2i2.415

\begin{abstract}
This study investigated the dynamic processes involved in problem solving in a web-based cooperative learning environment implemented for a university accounting course. 54 students were recruited in a 4-year hospitality management program. The messages of participants in group discussions were counted and categorized to investigate the dynamic processes of problem-solving employed by students. These dialogues and follow-up interviews revealed a number of interesting findings: (1) students felt that the web-based cooperative learning environment was similar to a social network; (2) peer-interaction in web-based cooperative learning is highly beneficial; (3) the course of study may influence the nature of problem-solving messages; (4) the teaching method could alter the cognitive level of problem-solving; (5) a co-working style was the most common approach employed in the web-based cooperative learning environment; (6) cooperative learning is becoming increasingly popular in education; (7) technological developments can be expected to boost the adoption of web-based cooperative learning.
\end{abstract}

Keywords: problem-solving, web-based learning, cooperative learning, accounting education

\section{Introduction}

Institutes of higher education are advocating the use of technology to support students who have grown up in a technological age (Lowry \& Flohr, 2004; Papadakis, Kalogiannakis, \& Zaranis, 2016). Over the past decade, network technology has been increasingly used as a training aid in what has been termed the "e-learning revolution" (Welsh, Wanberg, Brown, \& Simmering, 2003; Liaw, Huang, \& Chen, 2007). Advances in e-learning have had a considerable influence on the way that courses are taught (Glahn \& Glen, 2002; Katz, 2003; Veermans \& Cesareni, 2005; Li, Li, \& Teresa, 2016). E-learning has evolved from a repository of information to "a rich, multimedia environment" (Nam, 2014). Within the field of e-learning, virtual learning environments, such as various learning management systems (LMS), are a recent trend (Chipps, Kerr, Brysiewicz, \& Walters, 2015; Yeou, 2016).

Huang and Lin (2000) pointed out that the delivery of education can be achieved using three methods: individual learning, competitive learning, and cooperative learning (CL). Cooperative learning refers to the joint construction of knowledge by a group of people with a shared commitment to a common goal (Sharan, 1980). A CL setting can enhance learning by providing systematic instruction in which students are expected to complete various tasks (Barbara, Wagner, Reimann, \& Spiel, 2008). Boyce (2009) claimed that the type of instructional environment instructors implement conveys what they value and has motivational consequences for the students. CL has been defined as " . . a structured educational strategy integrating classroom studies with learning, through productive work experiences in a field related to a student's academic or career goals" (Ku, Tseng, \& Akarasriworn, 2013). This strategy involves developing a partnership between the student, the educational institution, and the workplace. The primary function of CL is to prepare students for the workplace by developing both generic and specific competencies that are believed to be useful to an employer (Rainsbury, Hodges, Burchell, \& Lay, 2002). Through CL, students take responsibility for their own learning by working in groups to solve problems; this involves exploring various resources to obtain an acceptable solution to the difficulties that they encounter (Johnson \& Johnson, 2009). Students are required to work cooperatively by 
assuming the roles of both learners and teachers (Mierson \& Freiert, 2004; Johnson, Johnson, \& Smith, 2007). In this manner, students construct knowledge by themselves and make meaningful cognitive, social, and experiential connections between prior knowledge and the newly acquired knowledge. The major strategies involved in CL include Student Team Achievement Division (STAD), Learning Together (LT), Teams-Games-Tournament (TGT), and Group Investigation (GI) (Jensen, Johnson, \& Johnson, 2002). Among these strategies, STAD (the most common) was adopted for this study. STAD was first developed by Slavin in 1979. It includes five stages of instruction: class presentation, group work, quizzes, individual improvement, and team recognition (Slavin, 1995).

The ability to create virtual environments on the internet means that CL need no longer be confined to traditional classrooms. The flexibility, interactivity, and boundless resources of the internet can help to overcome the limitations of conventional linear learning methods. Students no longer have to study alone; they can escape the boundaries of time and space to take part in group discussions. As a result, many scholars have promoted the use of the internet as a medium for CL. Hoskins and van Hooff (2005) described how university courses that traditionally have been taught using lectures with large numbers of students could benefit from e-learning methods. Many empirical studies have demonstrated that web-based CL can enhance learning effectiveness (Gabbin \& Wood, 2008; Ashcraft, 2008; Wang, 2010; Rhem \& Mills, 2012). Today, web-based CL is a hot topic in the study of learning environments and a major trend in instructional design (Weinberger \& Fischer, 2005; Dewiyanti, Brand-Gruwel, Jochems, \& Broers, 2007; Shimazoe \& Aldrich, 2010; Erhan ÜNAL \& Hasan ÇAKIR, 2017). Despite the widespread use of the internet as a medium for CL, many studies showed that the success of web-based learning may not be achieved (Yeou, 2016). Papadakis, Kalogiannakis, Sifaki, and Vidakis (2017) also indicated that learners accessed LMS for leaning materials much more than other uses. This is why this study wants to explore learners' dialogues through dynamic problem-solving process in a web-based learning environment. In other words, this paper aims to recognize if leaners' perceptions and behaviors would be adjusted under well-designed teaching strategies in a web-based learning environment.

Many business institutions offer e-learning courses via the internet to help employees acquire new knowledge and enhance their ability to solve customer problems (Chang \& Chen, 2009; Luor, Hu, \& Lu, 2009). Web-based $\mathrm{CL}$ is particularly important in accounting courses because business institutions are under tremendous competitive pressure to improve service quality and administrative efficiency (Shih \& Fang, 2004). Despite the importance of CL within the accounting curriculum, little research has been conducted on the application of CL in accounting courses. As a result, curriculum design for courses on CL in accounting relies on knowledge obtained in other fields. Many studies have provided empirical proof that CL can enhance learning effectiveness (Cavus, Uzunboylu, \& Ibrahim, 2007; Kyndt et al., 2013; Baloche \& Brody, 2017). Hite (1996) found that CL techniques have a particular influence on the academic achievement of accounting majors, to prepare graduates for a career in the accounting industry, and integrating a web-based cooperative learning technology into the coursework could provide considerable benefits. The Virtual Web College Platform (VWCP) was implemented to facilitate web-based cooperative learning for individuals enrolled in accounting courses. To evaluate the dynamic processes involved in problem-solving on this platform, this study enumerated and categorized messages shared among students in group discussion rooms.

\section{Methodology}

This study adopted a mixed method with conversation analysis (CA) and interview data collected and analyzed. CA is a method for investigating the structure and process of social interaction between humans (Peräkylä, 2008). The related participants, learning management system (LMS), and instructional designs were described below.

\subsection{Participants and Settings}

This study recruited 54 students enrolled in the 4-year hospitality management program at a university in Taiwan. The study lasted for 8 weeks, from April to June, 2017 using the web-based CL method proposed by Tomlinson and Henderson (1995). The materials provided for the study group were the same as those in the regular program, except that the students had to perform activities developed for web-based CL on the Virtual Web College Platform (VWCP).

\subsection{Virtual Web College Platform (VWCP)}

The Virtual Web College Platform (VWCP), one of learning management systems, was adopted in this study as Figure 1. After signing in, the researcher had access to browse and edit the "teacher office" and "classroom environment", as shown in Figures 2 and 3. 


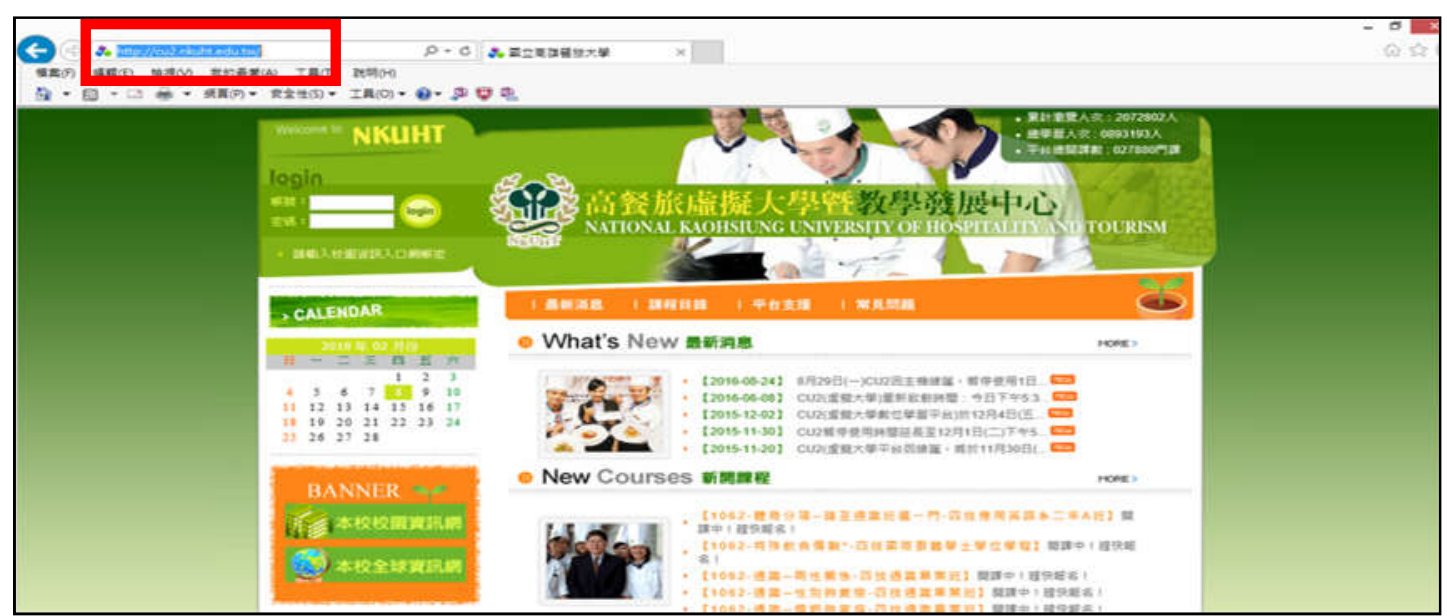

Figure 1. Virtual Web College Platform (VWCP)

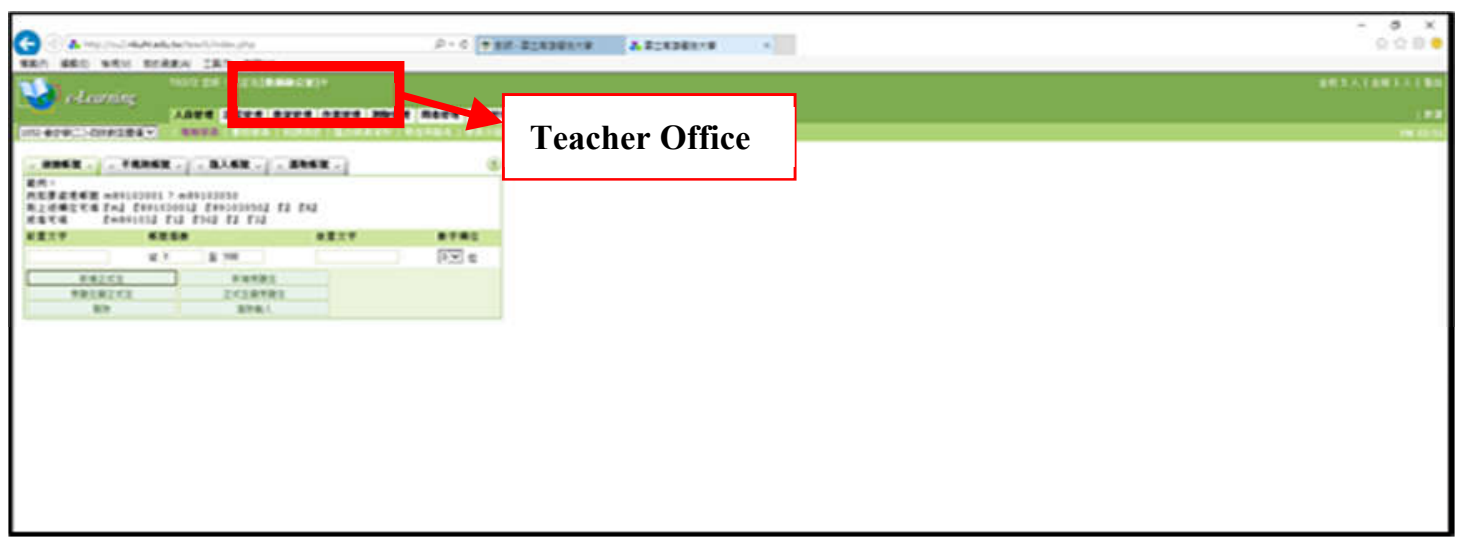

Figure 2. Teacher office

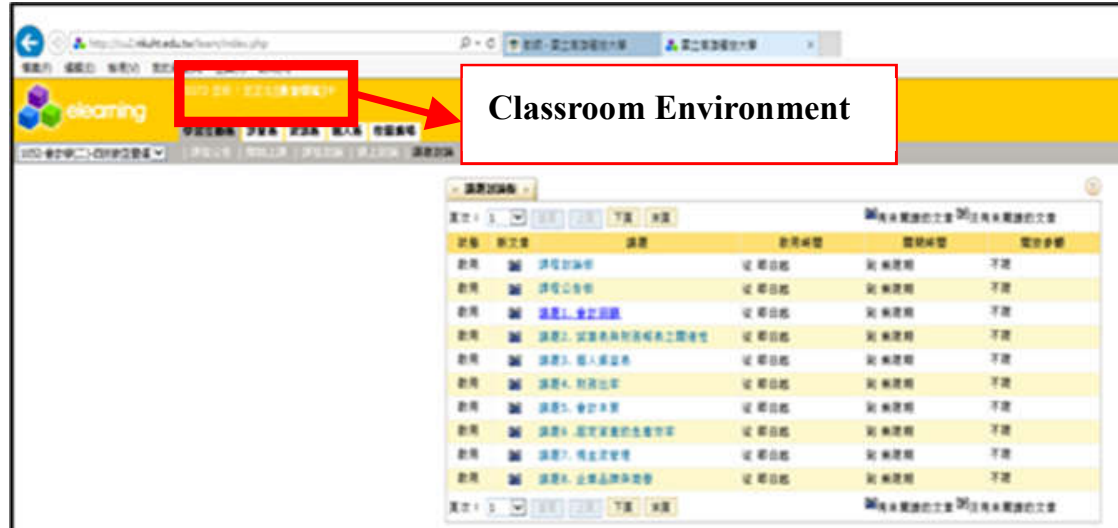

Figure 3. Classroom environment 
The following functions of VWCP were applied in the development of the web-based CL teaching environment.

\subsubsection{Attendance Statistics}

This function allowed the researcher to determine the attendance as well as the number and time of logins for each participant in the study.

\subsubsection{Student Grouping}

Following completion of the "accounting achievement test", this function was used to group online students according to the "heterogeneous grouping" principle of CL (Slavin, 1995).

\subsubsection{Management of Learning Paths}

This function allowed the researcher to develop web-based materials on the online platform and manage learning paths.

\subsubsection{Test Management}

This function enabled the researcher to manage questions for the "accounting achievement test".

\subsubsection{Discussion Forum}

This function allowed the researcher to post accounting-related topics for the teacher and students to discuss in asynchronous discussions.

\subsubsection{Group Discussion Room}

As shown in Figures 4 and 5, this function allowed the researcher to set up a discussion room for each learning group to facilitate synchronous discussions among members of each group. Each discussion room was independent and did not allow members of other groups to participate. The messages of participants were gathered for analysis. Each student was given an account and password for the VWCP. After logging into the system, students were automatically directed to the web-based course assigned to them. The quality of teaching design is the most critical aspect of any instructional activity. In this study, the teaching design was based on Cheng's (2011) evaluative criteria divided into three dimensions, including "content and structure of teaching materials", "design of teacher-student interactions", and "instructional design". Seven experts evaluated the eight instructional units, including "accounting is implicit knowledge", "let's increase the efficiency of fixed assets", "why isn't sea urchin sushi profitable", "why there should be more late-night supermarkets", "why do USD $\$ 3.99$ stir-fry restaurants make so much money", and "why is LV so expensive", "the one and only way to cut costs", and "people are fundamental", to ensure that the tasks were sufficiently challenging and suitable for cooperative activities. The teaching design was finalized according to the opinions of the experts.

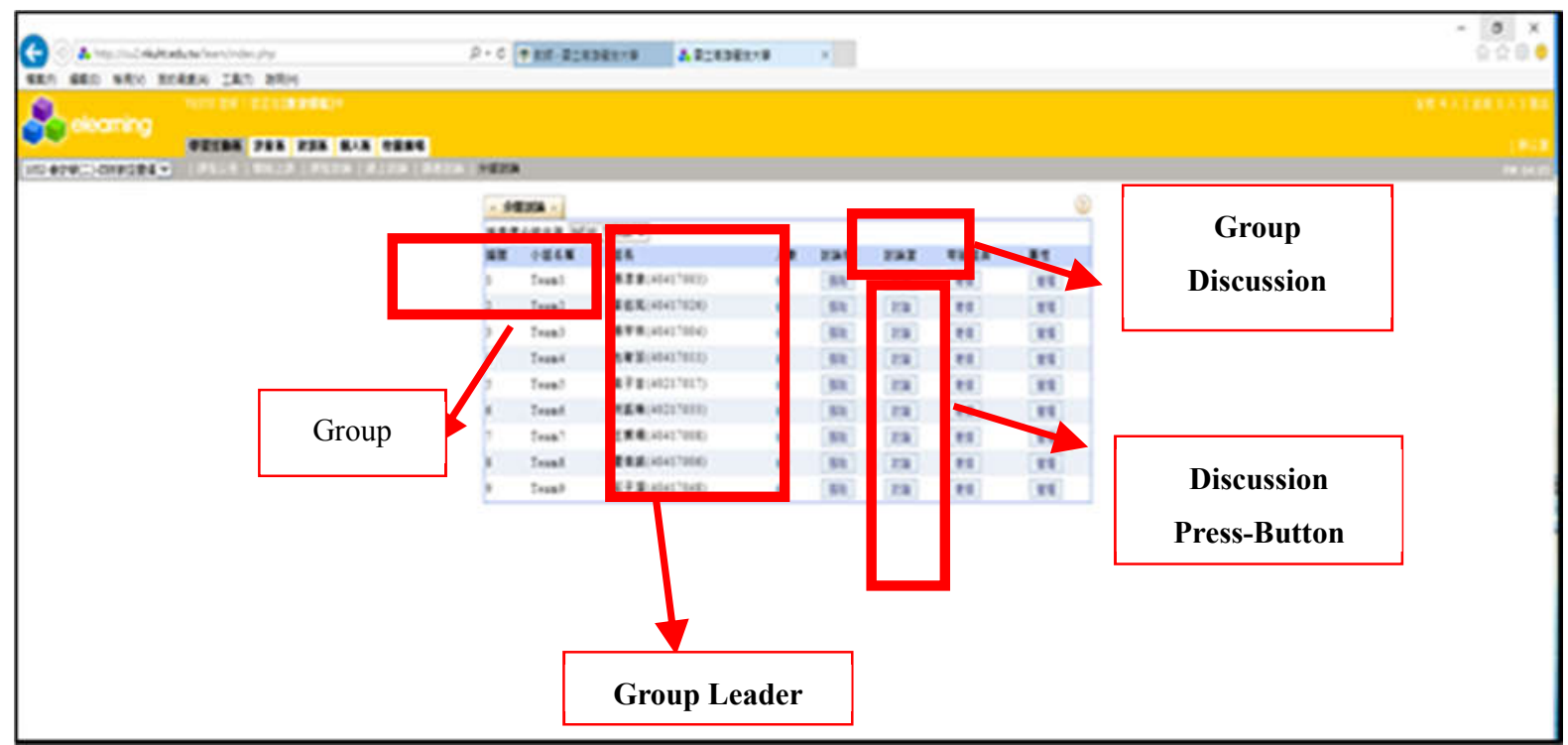

Figure 4. Group discussion function 


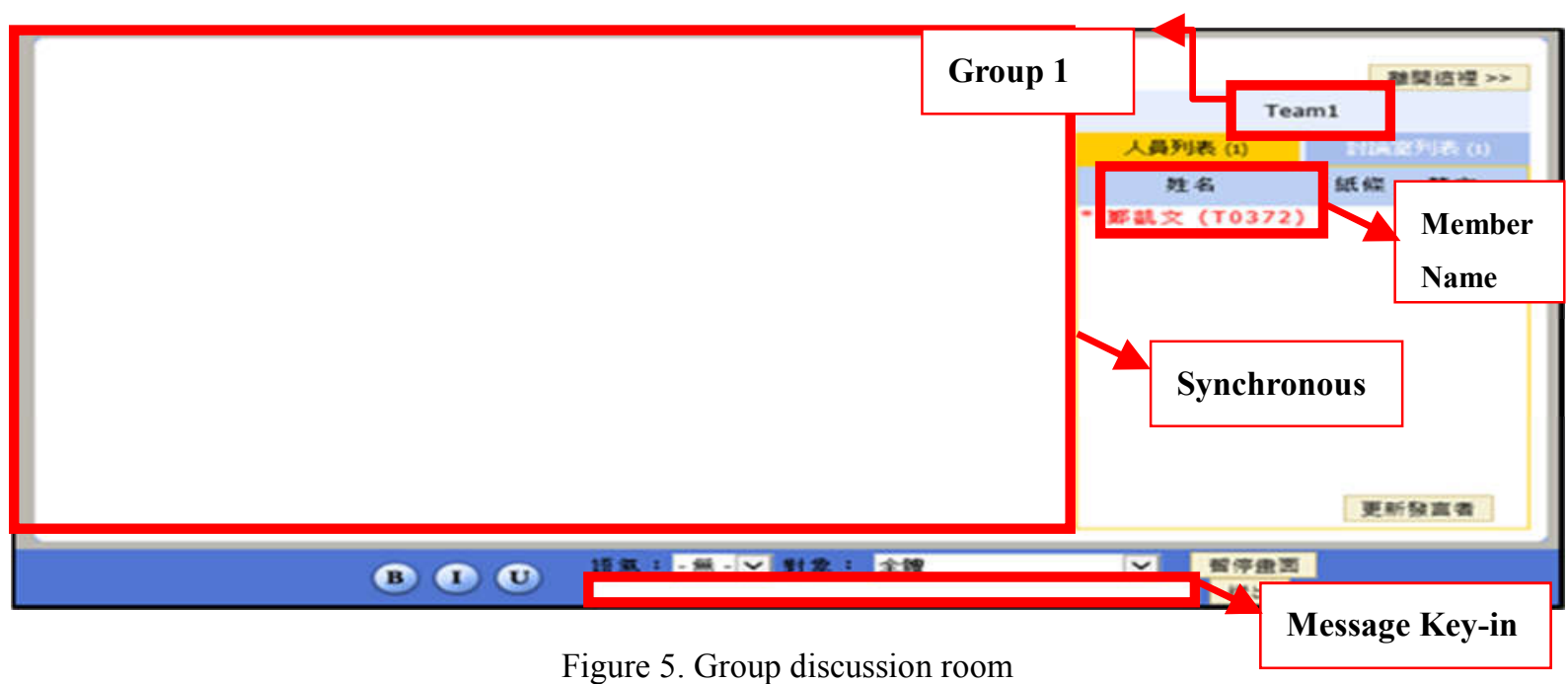

\subsection{Instructional Design of Web-based CL}

\subsubsection{Teaching Materials and Related Documents}

Six units of teaching materials were developed in accordance with the instructional design.

$>$ Implementation of the teaching activities

The teaching activities were divided into three sections, each of which detailed the schedule, content, required teaching aids, and notes related to the preparation activities, development activities, and general activities. The course spanned 8 weeks. A brief example is outlined as follows:

\section{Teaching Activity}

1. Preparation Activity

(1) Motivation

A. Do you know the main types of assets of a corporation?

B. How about the main types of liabilities of a corporation?

C. Then, what are the main types of owner equity of a corporation?

(2) Clarify the topic

This unit is intended to introduce accounting elements and accounts on the balance sheet of a corporation.

2. Development Activity

(1) Provide classroom instruction

A. Classification of accounting elements:

Assets, liabilities, and owner equity are the major elements of financial accounting. As owner equity includes income and expense, these five items (assets, liabilities, owner equity, income, and expenses), are commonly referred to as the five elements of financial accounting.

B. The meaning of accounts:

In accounting, an account is a vehicle used to identify and accumulate different financial transactions. Accounts can be classified into five categories; i.e., the five elements of accounting.

C. Introduction to accounts:

a. Accounts in the category of assets

a. Accounts in the category of liabilities

c. Accounts in the category of owner equity

d. Accounts in the category of income

a. Accounts in the category of expenses 
(2) Group cooperative learning

A. Present cooperative learning sheets.

B. Group cooperation and interaction: Each learning group is required to complete the learning sheets through interactive learning.

C. Present the answers to the cooperative learning sheets.

(3) Individual assessment

A. All students take an individual test.

B. The instructor provides answers and explanations.

3. Summary activity

Review the key points and collect feedback

$>$ Learning sheets

These "cooperative learning sheets" listed topics for group discussions to cultivate the spirit of CL.

$>$ Answers to the learning sheets

These provide answers to the problems on the learning sheets. Providing answers after the group discussion was meant to familiarize the students with these problems.

$>$ Quiz

A quiz was designed for each of the eight units, including "accounting is implicit knowledge", "let's increase the efficiency of fixed assets", "why isn't sea urchin sushi profitable", "why there should be more late-night supermarkets", "why do USD \$3.99 stir-fry restaurants make so much money", and "why is LV so expensive", "the one and only way to cut costs", and "people are fundamental".

Quiz answers

Providing the correct answers to the quiz was meant to enhance familiarity with the course content.

\section{$>$ Individual and group progress score table}

Previous studies demonstrated that grade incentives provide the most effective means to improve performance in a CL setting (Gabbin \& Wood, 2008; Ravenscroft \& Buckless, 1997; Ravenscroft et al., 1995). This involves computing student grades according to a combination of individual exam performance and the average exam performance of group members. In this study, individual progress scores were derived by deducting the basic score from the quiz score. The basic score was an average of the scores in previous quizzes, and the quiz score was the individual score of each quiz. The score table is shown in Table 1.

Table 1. Score table for individual and group progress

\begin{tabular}{lc}
\hline Individual progress score ( = quiz score-basic score) & Translated group score \\
\hline$-10+$ & 0 \\
$-0 \sim 9$ & 10 \\
$+1 \sim 9$ & 20 \\
$+10+$ & 30 \\
Excellent performance (above 90 or ranks top 3 in the class) & 40 \\
\hline
\end{tabular}

\subsubsection{Teaching Processes}

\section{$>$ Introduction and accounting achievement test}

In the first week of the course, the researcher presented a 50-minute introduction to the web-based teaching system and explained the implementation, evaluation, and content of the experimental teaching. An accounting achievement test was then administered to all participants. The test was divided into four sections, in accordance with the content of the accounting courses and expert opinions: enterprise and accounting, accounting information, basic accounting hypotheses, and accounting principles. To ensure face validity and content validity of the teaching materials, four accounting professors served as an expert group panel to review the teaching 
content. According to their opinions, a two-way specification table for the accounting achievement test was compiled as a reference for further revision (Kuo, 2000) (Table 2).

Table 2. Two-way specification table for the accounting achievement test

\begin{tabular}{|c|c|c|c|c|}
\hline Objective & Knowledge & Comprehension & Application & Total Numbe \\
\hline \multicolumn{5}{|l|}{ Teaching content } \\
\hline 1. Enterprise and accounting & 2 & 3 & 1 & 6 \\
\hline 2. Accounting information & 6 & 4 & 3 & 13 \\
\hline 3. Basic accounting hypotheses & 3 & 4 & 1 & 8 \\
\hline 4. Accounting principles & 9 & 10 & 4 & 23 \\
\hline Total Number & 20 & 21 & 9 & 50 \\
\hline
\end{tabular}

The two-way specification table enabled the compilation of the first draft of test content. Following a review of the expert panel, 110 questions were then finalized for the test. The researcher selected 204 students as pilot subjects for the test. Results from the pilot test were then submitted to difficulty analysis and discrimination analysis. As pointed out by Yei (2004), a difficulty value closest to .5 is the best. A t-test of extreme values was employed for discrimination analysis. Questions that were identified as excessively hard or easy $(\mathrm{p} \leqq .3$ or $p$ $\geqq .7$ ) were deleted, and those with a significant difference in the discrimination analysis were reserved (Chiu, 2004). The Kuder-Richardson reliability test (KR-20) was applied to assess the internal consistency of the overall scale and each sub-scale. The analysis results revealed that the reliability of the overall scale was .84 and those of sub-scales ranged between .36 .76, which were considered acceptable (Yei, 2004).

\section{$>$ Class instruction}

This step was intended to introduce major concepts, provide comprehensive summaries, or clarify basic concepts following group activities. Instruction related to the class procedures was performed before the class and at a number of important concepts were reviewed at end of the experimental process.

\section{$>$ Grouping and logging in}

Heterogeneous groups are required for effective CL. Students were divided according to their level of competency and logged into the teaching system with a given account. The grouping procedure is detailed as follows:

\section{$>$ Ranking}

The students were ranked according to the results of the accounting achievement test, which served as an index of competency.

\section{$>$ Group size}

The participants were divided into 9 groups of 6 members each.

\section{$>$ Grouping}

According to the results of the accounting achievement test, the students in each group were divided into three levels, high, mid, and low, in proportions of $25 \%, 50 \%$, and $25 \%$ respectively. Based on the ranking, the students were later assigned to the groups shown in Table 3. 
Table 3. Grouping method

\begin{tabular}{cccccccccc}
\hline Level & G1 & G2 & G3 & G4 & G5 & G6 & G7 & G8 & G9 \\
\hline High & 1 & 2 & 3 & 4 & 5 & 6 & 7 & 8 & 9 \\
& & & & & & 13 & 12 & 11 & 10 \\
\multirow{4}{*}{ Mid } & 18 & 17 & 16 & 15 & 14 & & & & \\
& 36 & 20 & 21 & 22 & 23 & 24 & 25 & 26 & 27 \\
& 37 & 38 & 34 & 33 & 32 & 31 & 30 & 29 & 28 \\
\multirow{2}{*}{ Low } & 54 & 53 & 52 & 51 & 50 & 49 & 48 & 47 & 46 \\
\hline
\end{tabular}

\section{$>$ Group discussion and learning}

Identical "cooperative learning sheets" were distributed to each group for discussion and practice, so that each group was assigned the same project. Members were expected to cooperate in solving the problems, and each member of the group was asked to take turns as the group leader for one week. This arrangement was meant to prevent students attempting to avoid participating in the assigned project. During practice sessions, the researcher observed the process to ensure that the group discussion proceeded in an appropriate manner. Suggestions for rectification and compliment were also provided. After all the groups had completed the "cooperative learning sheets" and published the results, the correct answers were released to deepen students' familiarity with the content of the unit.

\section{Evaluation of achievement in each unit}

After the students completed the learning sheets, the teacher tested their competency using a quiz.

\section{$>$ Awarding groups and individuals}

After converting the quiz scores into progress scores, the teacher awarded points to the groups and individuals with the highest progress scores in each unit. The recipients then had one additional point added to their final semester score for accounting.

\section{Inquiry of key points}

Prior to the end of each unit, group members could ask the teacher questions or engage in two-way discussions about the key points in the course content.

\section{Results}

\subsection{Categories of Participant Messages Saved From the Group Discussions}

This study counted the messages saved in the VWCP group discussion rooms (Table 4). All messages were gathered during class time. The total number of messages was 4,728, of which 2,600 were categorized as topical messages $(55 \%)$. The remaining 2,128 messages are off the topic (45\%). The categories were produced by three research assistants (all three research assistants had M.B.A degrees). Two research assistants implemented the first classification; the third research assistant conducted a second round to deal with inconsistencies. Among the discussion messages, 1,187 cognitive messages were delivered by the learners (45.7\%) and 1,413 cognitive messages were in response to peer-interactive replies (54.3\%). In Table 4, it can be seen that a large number of the messages were non-cognitive messages ( $45 \%$ ). $25 \%$ of all of the messages were focused on the discussion topic, and nearly $30 \%$ were responses to the messages of other participants. Most of the learners were excited about participating for the first time in a web-based CL course; therefore, many unrelated or "nonsense" dialogues were expected. According to Papadakis, Kalogiannakis, Sifaki, and Vidakis (2017), students preferred to use other social media platforms rather than LMS to interact with others, such as Facebook. However, it is showed that students may interact with peers frequently under web-based CL teaching strategy on the VWCP. 
Table 4. Categories of participant messages saved from the web-based CL discussion room

\begin{tabular}{|c|c|c|c|c|c|}
\hline \multirow{3}{*}{ Group } & \multicolumn{5}{|c|}{ Category } \\
\hline & \multicolumn{3}{|c|}{ Topical messages } & \multirow{2}{*}{$\begin{array}{l}\text { Off the topic } \\
\text { messages }\end{array}$} & \multirow{2}{*}{$\begin{array}{c}\text { Total } \\
\text { messages }\end{array}$} \\
\hline & Total messages & Discussion Issue & Peer-interactive Replies & & \\
\hline G1 & 317 & 134 & 183 & 270 & 587 \\
\hline $\mathrm{G} 2$ & 184 & 82 & 102 & 278 & 462 \\
\hline G3 & 209 & 76 & 133 & 306 & 515 \\
\hline G4 & 305 & 117 & 188 & 267 & 572 \\
\hline G5 & 298 & 147 & 151 & 267 & 565 \\
\hline G6 & 241 & 109 & 132 & 70 & 311 \\
\hline G7 & 252 & 126 & 126 & 253 & 505 \\
\hline G8 & 237 & 110 & 127 & 151 & 388 \\
\hline G9 & 557 & 286 & 271 & 266 & 823 \\
\hline Total & 2600 & 1187 & 1413 & 2128 & 4728 \\
\hline$\%$ & 54.99 & 25.10 & 29.89 & 45.01 & 100 \\
\hline
\end{tabular}

\subsection{Categories of Participant Messages Related to Problem-Solving}

In accordance with the findings of Klein and Doran (1999), Park and Bodzin (2000), Shin, Jonassen, and McGee (2003), Tseng, Chiang, and Hsu (2008), and Head and Alford (2015), nine categories of participant messages related to problem-solving were developed. According to analysis results (Table 5), "general explanations (GE)" accounted for most of the questions (49.60\%), followed by "raising questions (RQ)" (15.74\%) and "solving the problem (SP)" (13.9\%). "Brainstorming (BS)" (0.02\%), "Elaboration (EL)" (1.29\%) and "Organization (OZ)" $(2.47 \%)$ made up the smallest percentages. This was the first time that the students had to provide statements and responses to a topic in this manner; therefore, they lacked experience in higher-level problem-solving skills, considering that Taiwanese students seldom raise questions in class. The analysis results in Table 5 showing that messages among the groups were very similar, focusing on general explanations, reactions, questions, and problem solving. The web-based CL platform promoted cooperation among the students, stimulated students to ask questions, and enhanced the sharing of knowledge in every group. These findings are consistent with those of Beers, Boshuizen, Kirschner, and Gijselasers (2005) and Mozafari, Shiri, and Beigy (2015).

Table 5. Categories of participant messages related to problem-solving

\begin{tabular}{lcccccccccc}
\hline \multirow{2}{*}{ Group } & \multicolumn{8}{c}{ Category } & \multirow{2}{*}{ Total } \\
\cline { 2 - 9 } & GE & OZ & RQ & AN & EL & RE & BS & SP & RF & \\
\hline G1 & 265 & 15 & 92 & 25 & 5 & 80 & 0 & 70 & 35 & 587 \\
G2 & 294 & 6 & 39 & 5 & 0 & 41 & 0 & 62 & 15 & 462 \\
G3 & 330 & 4 & 56 & 18 & 17 & 38 & 0 & 32 & 20 & 515 \\
G4 & 322 & 14 & 89 & 12 & 0 & 47 & 1 & 65 & 22 & 572 \\
G5 & 295 & 13 & 98 & 20 & 4 & 55 & 0 & 65 & 15 & 565 \\
G6 & 76 & 9 & 55 & 15 & 3 & 37 & 0 & 92 & 24 & 311 \\
G7 & 298 & 4 & 80 & 2 & 3 & 29 & 0 & 66 & 23 & 505 \\
G8 & 188 & 21 & 79 & 6 & 9 & 24 & 0 & 46 & 15 & 388 \\
G9 & 277 & 31 & 156 & 44 & 20 & 92 & 0 & 159 & 44 & 823 \\
Total & 2343 & 117 & 744 & 147 & 61 & 443 & 1 & 657 & 213 & 4728 \\
\% & 49.60 & 2.47 & 15.74 & 3.11 & 1.29 & 9.37 & 0.02 & 13.9 & 4.5 & 100 \\
\hline
\end{tabular}

Description: GE: General Explanation; OZ: Organization; RQ: Raising Question; AN: Analysis; EL: Elaboration;

RE: Reaction; BS: Brainstorming; SP: Solving the Problem; RF: Reflection. 


\subsection{The Dynamic Process of Problem Solving in a Web-Based CL Environment}

The dynamic process of collaboratively solving problems was also explored. The approach proposed by Isaksen and Parnes (1985) was adopted to classify the discussion messages. These categories included "Identify the problem (P1)", "Collect data (P2)", "Discover problem (P3)", "Seek ideas (P4)", "Find a solution (P5)", and "Seek Acceptance (P6)". A summary of the dynamic problem-solving processes of the nine groups is presented in Figure 6.

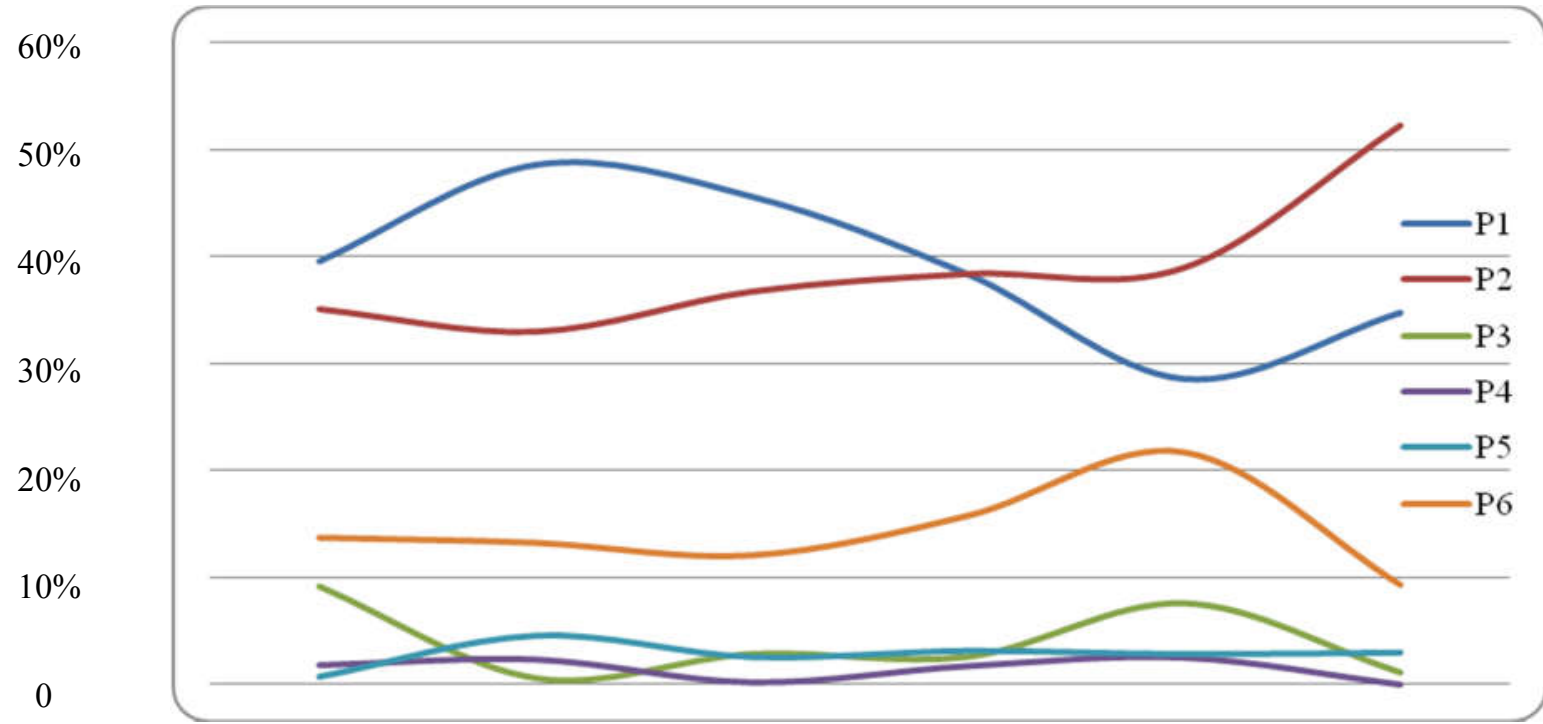

Figure 6. Summary of the dynamic problem-solving processes performed by the nine groups

A number of similarities were identified in the discussion messages of all the groups. First, every group spent a great deal of time identifying the problem, particularly in the earlier stages. Second, they also spent a lot of time collecting related resources and data or asking other members to solve the problems; this tendency increased rapidly in the later stages of the experiment. Third, most groups spent little time in the discovery of other problems, seeking ideas, or searching for alternatives to the problem-solving task. It is believed that most students are unaccustomed to solving problems spontaneously; they generally wait for the teacher's or other group members' to provide them with the answers. Another explanation may simply be that this was their first time participating in web-based CL activities. Fourth, the dynamic processes of problem-solving generally involved "identifying the problem" and to a lesser degree "collecting data" and "seeking acceptance". Surprisingly, "identifying the problem" made up the majority of comments in the early stages; however, this trend decreased rapidly in the following weeks, while "collecting data" and "seeking acceptance" gradually increased. Based on the study of Papadakis, Kalogiannakis, Sifaki, and Vidakis (2017), students would react differently depending on their skill and attitude to the online environment. It is obvious that students would adjust their perceptions and behaviors as they are familiar with this learning environment.

\subsection{Results of Participant Interviews}

\subsubsection{Results from Participant Interviews in 2017}

To better understand the views of students regarding this web-based cooperative learning method, two members of each group were randomly selected for interviews. As shown in Table 6, participant feedback can be grouped into six responses: (1) this method forced us to cooperate; (2) this experience is fresh and interesting; (3) this method allowed us to interact with other members more than we could in other courses; (4) this method enhanced our knowledge of accounting; (5) this method was sometimes a waste of time trying to convince members who refused to accept the answers of others; (6) most of the participants were initially unaccustomed to communicating by computer. 
Table 6. Feedback related to web-based cooperative environment in 2017

\begin{tabular}{|c|c|c|}
\hline Categories & Frequency & Example \\
\hline Forced to cooperate & 18 & $\begin{array}{l}\text { Because everyone had to be a leader in turn, each member was } \\
\text { forced to cooperate with the others and assume his/her } \\
\text { responsibilities. }\end{array}$ \\
\hline Fresh and interesting & 15 & $\begin{array}{l}\text { This teaching method is very interesting. I have never had this } \\
\text { kind of experience before. }\end{array}$ \\
\hline Greater interaction & 15 & $\begin{array}{l}\text { To be honest, I usually learn by myself; however, in this case I } \\
\text { spent a lot of time interacting with other members to complete the } \\
\text { assigned work. }\end{array}$ \\
\hline Enhanced knowledge of accounting & 13 & $\begin{array}{l}\text { Accounting is not easy for me. This method improved my } \\
\text { knowledge of accounting through the explanations and help of } \\
\text { other members. }\end{array}$ \\
\hline Occasionally a waste of time & 7 & $\begin{array}{l}\text { When we cooperated to complete the assigned project, a few } \\
\text { members insisted on their opinions and answers. We wasted time } \\
\text { persuading them that our answers were right. }\end{array}$ \\
\hline $\begin{array}{l}\text { Unaccustomed to communicating } \\
\text { by computer }\end{array}$ & 6 & $\begin{array}{l}\text { I am used to talking with my friends on Line; however, this was } \\
\text { my first time communicating with classmates to solve problems } \\
\text { using computers. I was not accustomed to it at first. }\end{array}$ \\
\hline
\end{tabular}

\subsubsection{Results from Follow-up Interviews}

To gain further insight, follow-up interviews were conducted, to reveal how the opinions of students towards this innovative teaching method had changed. Again, random interviews were conducted with two members of each group. The feedback was largely the same as that of former participants: (1) this method enhanced our knowledge of accounting; (2) this experience was interesting, and (3) this method forced us to cooperate. However, some different opinions appeared in the follow-up interview: (1) cooperating to finish a project is common in other courses; however, interacting by web is rare; and (2) interacting by web is similar to the interactions encountered on Facebook. The related categories are listed in Table 7.

Unlike the results suggested by Papadakis, Kalogiannakis, Sifaki, and Vidakis (2017), the results of this study showed that the creation of different instructional designs and teaching activities really generated learners' more frequent interactions and higher-level problem-solving skills.

Table 7. Follow-up feedback to web-based cooperative environment

\begin{tabular}{|c|c|c|}
\hline Categories & Frequency & Example \\
\hline Enhanced knowledge of accounting & 16 & $\begin{array}{l}\text { Through this method, we can discuss problems repeatedly, } \\
\text { which helps us to learn better. }\end{array}$ \\
\hline Interesting & 13 & $\begin{array}{l}\text { I have used this method before in other courses. However, it } \\
\text { was my first time using this method in business courses, } \\
\text { especially in accounting. It was an interesting experience. }\end{array}$ \\
\hline Enforced cooperation & 13 & $\begin{array}{l}\text { I think accounting is not easy to learn. This method forced } \\
\text { us to cooperate with other members to solve accounting } \\
\text { problems more smoothly. }\end{array}$ \\
\hline Classroom interaction by web is rare & 12 & $\begin{array}{c}\text { Cooperative learning is common in other courses, like } \\
\text { project seminars. However, cooperative learning by web is } \\
\text { rare. }\end{array}$ \\
\hline $\begin{array}{l}\text { Interacting by web is similar to is } \\
\text { similar to the interactions } \\
\text { encountered on Facebook }\end{array}$ & 10 & $\begin{array}{l}\text { We used Facebook everyday, even every hour. This method } \\
\text { made me think of Facebook. In truth, I am very accustomed } \\
\text { to this method because it is like a small Facebook. }\end{array}$ \\
\hline
\end{tabular}




\section{Discussion and Conclusions}

Problem solving is a cognitive processing aimed at figuring out how to achieve a goal (Campitelli \& Gobet, 2008; Mefoh, Nwoke, Chukwuorji, \& Chijioke, 2017). According to the results of the dialogues and interviews, web-based CL indeed has a positive influence on learning. The findings also provided evidence to support the following conclusions.

\subsection{Students Thought of Web-Based Cooperative Learning Environments as Social Networks}

Although interaction among students appeared frequent, most of these interactions were conversational in nature. According to the counts summarized in this study, the discussions among the group totaled 4,728 messages; however, 2,128 messages were off the topic (45\%). As revealed in the interview results of 2017, it is determined that most students were using this approach for the first time. Most of the students felt it was an interesting experience. They felt that this environment is similar to that of a social network, such as Line or Skype. This is likely the reason why the number of conversational chats was so high.

\subsection{Peer-Interaction in Web-Based Cooperative Learning Is Beneficial}

Among the discussion messages, 1,413 were cognitive in nature and made in response to the comments of their peers $(54.3 \%)$. Nearly $30 \%$ of all the responses were made in reply to the messages of other participants. As revealed in the interview results, students felt they had no choice but to cooperate and benefited from this. In order to complete the assigned projects and publish answers in class, the students had to identify the problems, collect related data, seek ideas, discuss repeatedly, and finally reach a unanimous answer. In this manner, the students developed their social skills while mastering accounting content. In addition, designing teaching strategy well can indeed force students to change their behaviors and to interact with others frequently.

\subsection{Learning Course may Influence the Categories of Problem-Solving Messages}

This study showed that high-level thinking, such as organization, analysis, elaboration, brainstorming, and reflection made up a relatively low percentage of the dialogues. However, the percentage of high level thinking in "solving the problem" accounted for a relatively high (13.9\%) percentage of the total dialogues. Accounting involves standardized steps to resolve the problems, which may explain why "solving the problem" required more high-level thinking. This study also designed cooperative sheets to ensure that each group solved problems and published their answers together. This may be another reason for the large number of messages related to "solving the problem".

\subsection{Teaching Method Has the Potential to Change the Levels of Problem-Solving}

Tracking the dynamic process of problem solving demonstrated by the nine groups, it was found that students spent a great deal of time identifying the problem during the discussions. Discovering other problems, seeking ideas, and finding alternatives for the problem-solving task were given far less attention. It is believed that most students are unaccustomed to solving problems themselves; they are used to waiting for other students or the teacher to provide the answers. Furthermore, it was interesting to note that even though "identifying the problem" was initially the main thrust of student efforts, "collecting data" and "seeking acceptance" increased in importance as time progressed. This implies that the teaching method employed could potentially change the level of problem solving from low to high. This viewpoint is consistent with that of Tennyson and Breuer (2002), Leary, Walker, Shelton, and Fitt (2013), and Huang (2014).

\subsection{Co-working Is the Most Common Approach in Web-Based Cooperative Learning Environments}

The dialogues in this study indicated two styles of cooperation in this study: (1) task-sharing, in which all members search for answers to some problems and seek assistance from other group members to deal with other problems; (2) co-working, in which members work on all of the problems individually and then discuss and complete the cooperative learning sheets together. Most groups in this study tended to adopt the co-working style. One possible reason for this may be that the participants had to take individual tests, despite the web-based cooperative design. In order to gain higher grades, most students naturally chose the co-working style.

\subsection{Cooperative Learning Is Gaining Popularity in Education}

As revealed in the interviews, many participants used web-based cooperative learning for the first time in 2017. However, other follow-up interviewees mentioned that they had similar experiences. This is a clear indication that the cooperative learning method is gaining popularity. Through cooperative learning, students learn to collect data, communicate, negotiate with other classmates, and finally reach an agreement. This process is just like the workplace environment that students will face in the future. Adopting cooperative learning gives students a taste of this situation. 


\subsection{Technological Innovation Boosts the Development of Web-Based Cooperative Learning}

As revealed in the follow-up interviews, students are becoming increasingly accustomed to environments similar to that found in web-based cooperative learning. This phenomenon is the result of developments in information technology and social networks, such as Facebook, Twitter, and IG. This trend indicates that further advances in technology will boost the development of web-based cooperative learning in the future.

\section{References}

Ashcraft, D. (2008). Collaborative online learning: a constructivist example. Journal of Online Leaning and Teacher, 4(1), 109-117.

Baloche, L., \& Brody, C. M. (2017). Cooperative learning: exploring challengers, crafting innovations. Journal of Education for Teaching, 43(3), 274-283. https://doi.org/10.1080/02607476.2017.1319513

Barbara, S., Wagner, P., Reimann, R., \& Spiel, C. (2008). Vienna E-Learning (VEL): Learning How to Learn Self-Regulated in an Internet-Based Blended Learning Setting. International Journal on E-Learning, 7(4), 703-723.

Beers, P. J., Boshuizen, H. P. A., Kirschner, P. A., \& Gijselaers, W. H. (2005). Computer support for knowledge construction in cooperative learning environments. Computers in Human Behavior, 21, 623-643. https://doi.org/10.1016/j.chb.2004.10.036

Boyce, B. A. (2009). Creating Instructional Environments that keep Students on TARGET. Journal of Physical Education, Recreation, and Dance, 80(1), 49-55. https://doi.org/10.1080/07303084.2009.10598268

Campitelli, G., \& Gobet, F. (2008). The role of practice in chess: A longitudinal study. Learning and Individual Differences, 18, 446-458. https://doi.org/10.1016/j.lindif.2007.11.006

Cavus, N., Uzunboylu, H., \& Ibrahim, D. (2007). Assessing the success of students using a learning management system and together with a collaborative in web-based teaching of programming languages. Journal of Educational Computing Research, 36(3), 301-321. https://doi.org/10.2190/T728-G676-4N18-6871

Chang, T. Y., \& Chen, Y. T. (2009). Cooperative learning in E-learning: A peer assessment of student-centered using consistent fuzzy preference. Expert Systems with Applications, 36, 8342-8349. https://doi.org/10.1016/j.eswa.2008.10.050

Cheng, K. W. (2011). Enhancing Students' Business Creativity through Adoption of an Innovative Teaching Strategy in Taiwan. Journal of Hospitality, Leisure, Sport and Tourism education, 10(2), 109-120. https://doi.org/10.3794/johlste.102.292

Chipps, J., Brysiewicz, p., \& Walters, F. (2015). A Survey of University Students' Perceptions of Learning Management Systems in a Low-Resourse Setting Using a Technology Acceptance Model. CIN: Cmputers, Informatics, Nursing, 33(2), 71-77.

Chiu, H. J. (2004). Quatitative Research and Statistical Analysis in Social \& Behavioral Sciences. Wu-Nan Culture Enterprise.

Dewiyanti, S., Brand-Gruwel, S., Jochems, W., \& Broers, N. J. (2007). Students' experiences with collaborative learning in asynchronous computer-supported collaborative learning environments. Computers in Human Behavior, 23(1), 496-514. https://doi.org/10.1016/j.chb.2004.10.021

Erhan ÜNAL, \& Hasan ÇAKIR. (2017). Students' Views about the Problem Based Collaborative Learning Environment Supported By Dynamic Web Technologies. Malaysian Online Journal of Educational Technology, 5(2), 1-19.

Gabbin, A. L., \& Wood, L. I. (2008). An Experimental Study of Accounting Majors' Academic Achievement Using Cooperative Learning Groups. Issues in Accounting Education, 23(3), 391-404. https://doi.org/10.2308/iace.2008.23.3.391

Glahn, R., \& Glen, R. (2002). Progenies in education: The evolution of internet teaching. Community College Journal of Research and Practice, 26, 777-785. https://doi.org/10.1080/10668920290104868

Head, B. W., \& Alford, J. (2015). Wicked Problems: Implications for Public Policy and Management. Administration \& Society, 47(6), 711-739. https://doi.org/10.1177/0095399713481601

Hite, P. (1996). A treatment study of the effectiveness of group exams in an individual income tax class. Issues in Accounting Education, 11(1), 61-75.

Hoskins, S. L., \& Van Hooff, J. C. (2005). Motivation and ability: which students use online learning and what 
influence does it have on their achievement? British Journal of Educational Technology, 36, 177-192. https://doi.org/10.1111/j.1467-8535.2005.00451.x

Huang, C. J., \& Lin, P. H. (2000). Cooperative Learning. Taipei: Wunan.

Huang, J. J. (2014). The flipped classroom and its concept, problems, and perspectives. Taiwan Educational Review Monthly, 3(12), 161-186.

Isaksen, S. G., \& Parnes, S. J. (1985). Curriculum Planning for Creative Thinking and Problem Solving. The Journal of Creative Behavior, 19(1), 1-29. https://doi.org/10.1002/j.2162-6057.1985.tb00400.x

Jensen, M., Johnson, D. W., \& Johnson, R. T. (2002). Impact of positive interdependence during electronic quizzes on discourse and achievement. The Journal of Educational Research, 95(3), 161-166. https://doi.org/10.1080/00220670209596586

Johnson, D. W., \& Johnson, R. T. (2009). An Educational Psychology Success Story: Social Interdependence Theory and Cooperative Learning. Educational Researcher, 38(5), 365-379. https://doi.org/10.3102/0013189X09339057

Johnson, D. W., Johnson, R. T., \& Smith, K. (2007). The State of Cooperative Learning in Postsecondary and $\begin{array}{llll}\text { Professional Settings. Educational Psychology } & \text { Review, } & 19(1), & \text { 15-29. }\end{array}$ https://doi.org/10.1007/s10648-006-9038-8

Katz, R. (2003). Balancing technology and tradition: The example of course management systems. EDUCAUSE Review, 38(4), 48-59.

Klein, J. D., \& Doran, M. S. (1999). Implementing individual and small group learning structures with a computer simulation. Educational Technology, Research and Development, 47(1), 97-110. https://doi.org/10.1007/BF02299479

Ku, H. Y., Tseng, H. W., \& Akarasriworn, C. (2013). Collaboration factors, teamwork satisfaction, and student attitudes toward online collaborative learning. Computers in Human Behavior, 29(3), 922-929. https://doi.org/10.1016/j.chb.2012.12.019

Kuo, S. Y. (2000). Psychology and Education Test. Taipei: Chinghua.

Kyndt, E., Raes, E., Lismont, B., Timmers, F., Cascallar, E., \& Dochy, F. (2013). A meta-analysis of the effects of face-to-face cooperative learning. Do recent studies falsify or verify earlier findings? Educational Research Review, 10, 133-149. https://doi.org/10.1016/j.edurev.2013.02.002

Leary, H., Walker, A., Shelton, B. E., \& Fitt, M. H. (2013). Exploring the Relationships between Tutor Background, Tutor Training, and Student Learning: A Problem-based Learning Meta-Analysis. Interdisciplinary Journal of Problem-based Learning, 7(1), 39-66. https://doi.org/10.7771/1541-5015.1331

Li, K., Li, Y., \& Teresa, F. (2016). Preservice Teachers' Intention to Adopt Technology in Their Future Classrooms. Journal of Educational Computing Research, 54(7), 946-966. https://doi.org/10.1177/0735633116641694

Liaw, S. S., Huang, H. M., \& Chen, G. D. (2007). Surveying instructor and learner attitudes toward e-learning. Computers and Education, 49(4), 1066-1080. https://doi.org/10.1016/j.compedu.2006.01.001

Lowry, L. L., \& Flohr, J. K. (2004). Technology and Change: A Longitudinal Case Study of Students' Perceptions of and Receptiveness to technology Enhanced Teaching and Learning. Journal of Teaching in Travel \& Tourism, 4(1), 15-39. https://doi.org/10.1300/J172v04n01_02

Luor, T. Y., Hu, C. Y., \& Lu, H. P. (2009). Mind the gap: An empirical study of the gap between intention and actual usage of corporate e-learning programmes in the financial industry. British Journal of Educational Technology, 40(4), 713-732. https://doi.org/10.1111/j.1467-8535.2008.00853.x

Mefoh, P. C., Nwoke, M. B., Chukwuorji, J. C., \& Chijioke, A. O. (2017). Effect of cognitive style and gender on adolescents' problemsolving ability. Thinking Skills and Creativity, 25, 47-52. https://doi.org/10.1016/j.tsc.2017.03.002

Mierson, S., \& Freiert, K. (2004). Problem-Based Learning. Training and Development, 58(10), 15-17.

Mozafaria, M., Shiria, M. E., \& Beigyba, H. (2015). A cooperative learning method based on cellular learning automata and its application in optimization problems. Journal of Computational Science, 11, 279-288. https://doi.org/10.1016/j.jocs.2015.08.002

Nam, C. W. (2014). The effects of trust and constructive controversy on student achievement and attitude in 
online cooperative learning environments. Computers in Human Behavior, 37, 237-248. https://doi.org/10.1016/j.chb.2014.05.007

Papadakis, S., Kalogiannakis, M., \& Zaranis, N. (2016). Developing Fundamental Programming Concepts and Computational Thinking with ScratchJr in Preschool Education: A Case Study. International Journal of Mobile Learning and Organisation, 10(3), 187-202.

Papadakis, S., Kalogiannakis, M., Sifaki, E., \& Vidakis, N. (2017). Access Moodle Using Smart Mobile Phones. A Case Study in a Greek University. In Interactivity, Game Creation, Design, Learning, and Innovation (pp. 376-385). Cham: Springer.

Park, J. C., \& Bodzin, A. M. (2000). Dialogue pattern of preservice science teachers: Using asynchronous computer-mediated communications on the worldwide web. Journal of Computers in Mathematics and Science Teaching, 19(2), 161-194.

Peräkylä, A. (2008). Conversation analysis and psychoanalysis: Interpretation, affect, and intersubjectivity. In PerŠkylŠ, A., Antaki, C., VehvilŠinen, S., \& Leudar, I. (Eds.), Conversation Analysis and Psychotherapy (pp. 100-119). Cambridge: Cambridge University Press. https://doi.org/10.1017/CBO9780511490002.007

Rainsbury, E., Hodges, D., Burchell N., \& Lay, M. (2002). Ranking workplace competencies: Student and graduate perceptions. Asia-Pacific Journal of Cooperative Education, 3(2), 8-18.

Ravenscroft, S., \& Buckless, F. (1997). Student team learning- Replication and extension. Accounting Education: A Journal of Theory, Practice and Research, 2(2), 151-172.

Ravenscroft, S., Buckless, F., McCombs, G., \& Zuckerman, G. (1995). Incentives in student team learning: An experiment in cooperative group learning. Issues in Accounting Education, 10(1), 97-109.

Rhem, J., \& Millis, B. (2012). Cooperative learning in higher education: Across the disciplines, across the academy. Sterling, VA: Stylus Publishing LLC.

Sharan, S. (1980). Cooperative Learning in Small Groups: Recent Methods and Effects on Achievement, Attitudes, and Ethic Relations. Review of Education Research, 50(2), 241-271. https://doi.org/10.3102/00346543050002241

Shih, Y. Y., \& Fang, K. (2004). The use of a decomposed theory of planned behavior to study Internet banking in Taiwan. Internet Research, 14(3), 213-223. https://doi.org/10.1108/10662240410542643

Shimazoe, J., \& Aldrich, H. (2010). Group Work Can be Gratifying: Understanding \& Overcoming Resistance to Cooperative Learning. College Teaching, 58(2), 52-57. https://doi.org/10.1080/87567550903418594

Shin, N., Jonassen, D. H., \& McGee, S. (2003). Predictors of well-structured and ill-structured problem solving in an astronomy simulation. Journal of Research in Science Teaching, 40(1), 6-33. https://doi.org/10.1002/tea. 10058

Slavin, R. E. (1995). Cooperative learning: Theory, research and practice. Englewood Cliffs, NJ: Prentice-Hall.

Tennyson, R. D., \& Breuer, K. (2002). Improving problem solving and creativity through use of complex-dynamic simulations. Computer in Human Behavior, 18(6), 650-668. https://doi.org/10.1016/S0747-5632(02)00022-5

Tomlinson, H., \& Henderson, W. (1995). Computer supported collaborative learning in schools: A distributed

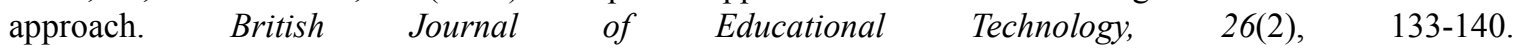
https://doi.org/10.1111/j.1467-8535.1995.tb00130.x

Tseng, K. H., Chiang, F. K., \& Hsu, W. H. (2008). Interactive processes and learning attitudes in a web-based problem-based learning (PBL) platform. Computers in Human Behavior, 24, 940-955. https://doi.org/10.1016/j.chb.2007.02.023

Veermans, M., \& Cesareni, D. (2005). The nature of the discourse in web-based collaborative learning environments: Case studies from four different countries. Computers and Education, 45(3), 316-336. https://doi.org/10.1016/j.compedu.2005.04.011

Wang, M. J. (2010). Online collaboration and offline interaction between students using asynchronous tools in blended learning. Australasian Journal of Educational Technology, 26(6), 830-846. https://doi.org/10.14742/ajet.1045

Weinberger, A., \& Fischer, F. (2005). A framework to analyze argumentative knowledge construction in computer-supported collaboration learning. Computers \& Education, 46(1), 71-95. 
https://doi.org/10.1016/j.compedu.2005.04.003

Welsh, E. T., Wanberg, C. R., Brown, K. G., \& Simmering, M. J. (2003). E-learning: emerging uses, empirical results and future directions. International Journal of Training and Development, 7(4), 245-258. https://doi.org/10.1046/j.1360-3736.2003.00184.x

Yei, C. S. (2004). Education research methodology. Taipei: Psychological Publishing Co. Ltd.

Yeou, M. (2016). An Investigation of students' Acceptance of Moodle in a Blended Learning Setting Using Technology Acceptance Model. Journal of educational Technology Systems, 44(3), 300-318. https://doi.org/10.1177/0047239515618464

\section{Copyrights}

Copyright for this article is retained by the author(s), with first publication rights granted to the journal.

This is an open-access article distributed under the terms and conditions of the Creative Commons Attribution license (http://creativecommons.org/licenses/by/4.0/). 